\title{
Markets for Concentrating Solar Power
}

As concentrating solar power technologies advance into the early stages of commercialization, their economic potential becomes more sharply defined and increasingly tangible.

Concentrating solar power - three technologies, each with special features and unique market advantages.

\section{Current Cost and Status}

The concentrating solar power industry has a decade-long performance record, one that can substantiate current and projected energy costs. This performance is with trough plants, the most mature of the three concentrating solar technologies. Because they are hybrid plants that operate on natural gas during cloudy periods, trough plants underscore the potential for concentrating solar technologies to combine with fossil fuel technology to take advantage of market opportunities.

The levelized energy cost (LEC) of solar energy from hybrid trough plants is $12 \$$ per kilowatt-hour (kWh). At this price, solar power is currently too expensive to compete in North America's bulk power markets; but it can compete in certain high-value and niche markets -

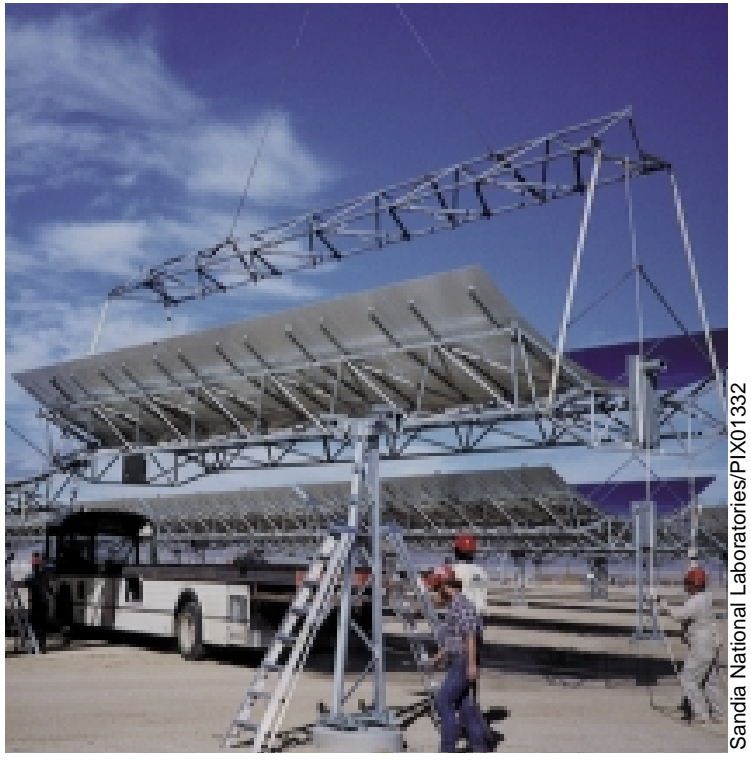

Concentrating solar power plants create $2^{1 / 2}$ times as many skilled high-paying jobs for the communities in which they operate as do conventional power plants that use fossil fuels.

\begin{tabular}{|c|c|c|c|c|c|c|}
\hline \multicolumn{7}{|c|}{ Concentrating Solar Power Technology Status and Projected Cost } \\
\hline & \multirow[t]{2}{*}{$\begin{array}{l}\text { Technology } \\
\text { Status }\end{array}$} & \multirow[t]{2}{*}{$\begin{array}{l}\text { Unit } \\
\text { Capacity }\end{array}$} & \multirow[t]{2}{*}{$\begin{array}{l}\text { Capital } \\
\text { Cost } \\
(\$ / k W)\end{array}$} & \multirow[t]{2}{*}{$\begin{array}{l}\text { O\&M } \\
(\boldsymbol{c} / \mathbf{k W h})\end{array}$} & \multicolumn{2}{|c|}{ LEC ( $\propto / \mathbf{k W h})$} \\
\hline & & & & & 2000 & 2010 \\
\hline Troughs & $\begin{array}{l}\text { Early } \\
\text { commercial } \\
\text { evolution }\end{array}$ & $\begin{array}{l}30 \mathrm{MW} \\
\text { to } \\
80 \mathrm{MW}\end{array}$ & $\$ 2,900$ & 1.0 & $6.8-11.2$ & $5.6-9.1$ \\
\hline $\begin{array}{l}\text { Power } \\
\text { Towers }\end{array}$ & $\begin{array}{l}\text { Demonstrated } \\
\text { technical } \\
\text { feasibility }\end{array}$ & $\begin{array}{l}30 \mathrm{MW} \\
\text { to } \\
200 \mathrm{MW}\end{array}$ & $\begin{array}{l}\$ 2,400 \text { to } \\
\$ 2,900\end{array}$ & 0.7 & $5.2-8.6$ & 3.3-5.4 \\
\hline $\begin{array}{l}\text { Solar Dish/ } \\
\text { Engines }\end{array}$ & $\begin{array}{l}\text { Early } \\
\text { technical } \\
\text { feasibility }\end{array}$ & $\begin{array}{l}5 \mathrm{~kW} \text { to } \\
50 \mathrm{~kW}\end{array}$ & $\$ 2,900$ & 2.0 & $8.6-13.0$ & $4.0-6.0$ \\
\hline
\end{tabular}


for example, for peak power. As the technology develops, costs will decrease further and new markets will open.

Capital costs for solar technologies are higher than for conventional power technologies, and operating costs are lower. Because capital costs must be amortized over the lifetime of the plant much the same way a mortgage is on a private home, project financing, interest rates, and tax policy heavily influence a solar project developer in many of the same ways they do an individual homeowner. As a result, the solar power industry is looking to compete in regions where policy stimulates developments such as enterprise zones, distributed generation, and niche markets.

\section{Niche Markets for Short-Term Gain}

Analysts predict the opening of specialized niche markets in this country for the solar power industry over the next 5 to 10 years. The U.S. Department of Energy estimates that by 2005, there will be as much as 500 megawatts (MW) of concentrating solar capacity installed worldwide.

Perhaps the first of these niche markets to establish itself will be solar enterprise zones. Built to promote local economic development, these markets could enjoy special treatment by policymakers and lawmakers. Policies include tax equity such as accelerated depreciation of capital expenses, standard permitting, project financial structure, and allowing construction of multiple projects at a single location resulting in reduced operation and maintenance $(\mathrm{O} \& \mathrm{M})$ costs.

With restructuring of the domestic utility industry, these projects will be able to market their electricity directly to consumers by packaging the solar electricity as environmentally friendly. Many consumers participating in "green marketing" programs are willing to pay slightly higher prices and are choosing electricity suppliers who are environmentally friendly. Solar power can produce electricity in the price range that many environmentally conscious consumers are currently paying in these programs.

\section{Export for Long-Term Growth}

Most of the world does not enjoy the inexpensive power supplies that we in the United States do, so for many people, concentrating solar power offers a secure, indigenous energy supply. Solar is most competitive in areas where the infrastructure, such as natural gas pipelines, is either insufficient or not guaranteed.

Furthermore, many areas that are experiencing economic growth and will require substantial new power capacity in the next 10 years have excellent solar resources. These areas have good sites both for large-scale power projects consisting of troughs and power towers and for small-scale projects consisting of dish/engine systems for distributed or local grid support.

\section{Countries With Good Solar Resources and Growing Economies}

$\begin{array}{lr}\text { Country } & \begin{array}{r}\text { New Capaci } \\ \text { Needed by 2005 }\end{array} \\ \text { Argentina } & 15,000 \\ \text { Brazil } & 23,000 \\ \text { China } & 192,000 \\ \text { Egypt } & 5,000 \\ \text { India } & 80,000 \\ \text { Mexico } & 15,000 \\ \text { Pakistan } & 10,000 \\ \text { South Africa } & 1,000 \\ \text { Turkey } & 15,000\end{array}$

Finally, there is a huge, as yet untapped, market for supplying power to the $40 \%$ of the world that does not yet have a reliable supply of electricity. Most of these people live in remote villages, many of which lie in the sun belt. Operating independently of a power transmission grid, dish/engines can supply electricity to villages or be used for applications such as water pumping and agriculture. Dish/engines will compete extremely well with diesel engines for these applications on the basis of performance, environmental impact, and cost. As solar power technology develops and costs become more competitive, its place in local and international markets will greatly expand.

For on-line information about the U.S. Department of Energy's Concentrating Solar Power Program, please visit its web site: http://www.eren.doe.gov/sunlab

For more information on renewable energy or for additional copies of this brochure, contact the Energy Efficiency and Renewable Energy Clearinghouse (EREC): 1-800-DOE-EREC (363-3732)

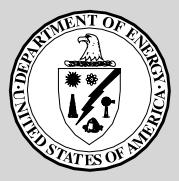

Produced for the

U.S. Department of Energy (DOE) 1000 Independence Avenue, S.W.

Washington, DC 20585-0121

Produced by Sun`Lab:

Bringing together solar energy expertise from Sandia National Laboratories and the National Renewable Energy Laboratory, DOE national laboratories.

DOE/GO-10098-563

April 1998

Printed on recycled paper 